\title{
PREDIKAT KOMPLEKS DALAM BAHASA ANGKOLA MANDAILING
}

\author{
Latifah Yusri Nasution \& Mulyadi \\ Universitas Sumatera Utara \\ e-mail:latifahyusri22@gmail.com
}

\begin{abstract}
Abstrak
Predikat kompleks terbentuk ketika dua atau lebih elemen predikat bergabung ke dalam hubungan subjek dan objek. Penelitian tentang predikat komplek bahasa Angkola Mandailing merupakan media mempelajari bahasa daerah yang mulai ditinggalkan. Penelitian ini bertujuan mendeskripsikan konstruksi predikat kompleks bahasa Angkola Mandailing. Penelitian menggunakan pendekatan kualitatif dengan metode interaktif dengan teori X-bar. Sumber data penelitian adalah tuturan lisan informan dalam situasi tutur yang alamiah. Pengumpulan data dengan metode simak atau observasi. Analisis dilakukan selama pengumpulan, reduksi, penyajian, dan penarikan simpulan/verifikasi. Analisis data menggunakan metode agih dan disajikan menggunakan metode informal. Hasil penelitian sebagai berikut. Pertama, karakteristik predikat kompleks dalam bahasa Angkola Mandailing, yaitu dibentuk dari dua verba atau lebih, letaknya berdampingan, dan memiliki kesamaan aspek dan negasi. Kedua, pola pembentuk predikat kompleks dalam bahasa Angkola Mandailing berupa V1 intransitif + V2 intransitif, V1 transitif + V2 intransitif, V1 intransitif + V2 transitif, dan V1 transitif + V2 transitif. Ketiga, kedua verba atau lebih dalam konstruksi predikat kompleks bahasa Angkola Mandailing samasama menjadi verba inti dalam kalimat. Skema X-barnya ialah predikat kompleks (V1+V2) berkombinasi membentuk V'. V' membentuk FV. FV berkombinasi dengan I membentuk I'. I' berkombinasi dengan Spes membentuk FI (kalimat).
\end{abstract}

Kata Kunci: konstruksi, predikat kompleks, bahasa Angkola Mandailing

\section{COMPLEX PREDICATE IN ANGKOLA MANDAILING LANGUAGE}

\begin{abstract}
Complex predicates are formed when two or more predicate elements are joined into the relationship of subject and object. Research on the predicate of the Angkola Mandailing language complex is a medium for learning the languages of the region that are becoming obsolete. This study aims to describe the construction of the Angkola Mandailing language complex. The study uses a qualitative approach with interactive methods with X-bar theory. The source of the research data is the oral speech of informants in natural speech situations. Data collection by listening or observing methods. The analysis is carried out during the collection, reduction, presentation, and
\end{abstract}


conclusions/ verification. Data analysis uses the aggregate method and is presented using the informal method. The results of this study indicate that. Fisrt, the characteristics of complex predicates in the Angkola Mandailing language, which are formed from two or more verbs, are located side by side, and have similar aspects and negations. Second, complex predicate pattern forming in Angkola Mandailing language is intransitive V1 + intransitive $\mathrm{V} 2$, transitive $\mathrm{V} 1+$ intransitive $\mathrm{V} 1$, intransive $\mathrm{V} 1+$ transitive $\mathrm{V} 2$, and transitive V1 + transitive V2. Third, the two or more verbs in the construction of the Angkola Mandailing language complex predicate together become the core verbs in the sentence. The X-bar scheme is a complex predicate $(\mathrm{V} 1+\mathrm{V} 2)$ combined to form $\mathrm{V}$ '. V 'forms VP. VP combines with I to form I '. I 'combines with Spes to form IP (sentence).

Keywords: construction, complex predicate, Angkola Mandailing language

\section{PENDAHULUAN}

Bahasa Angkola Mandailing adalah bahasa yang digunakan oleh masyarakat yang tinggal di kawasan Angkola Mandailing yang berada di empat wilayah kabupaten, yaitu Kabupaten Tapanuli Selatan, Kabupaten Mandailing Natal, Kabupaten Padang Lawas Utara, dan Kabupaten Padang Lawas. Dalam bahasa Angkola Mandailing terdapat dua predikat beruntun dalam satu kalimat. Dua predikat beruntun tersebut dinamakan predikat kompleks.

Predikat kompleks adalah predikat yang multi inti, yaitu predikat yang dibentuk oleh lebih dari satu unsur gramatikal (baik kata maupun morfem) yang masing-masing memberikan kontribusi informasi terkait dengan satu inti (Alsina, Bresnan, \& Sels, 1997 bandingkan dengan Hendrickx, 2010:100; Subiyanto, 2010:177). Dalam hal ini ada dua verba yang membentuk predikat. Kedua verba tersebut memiliki fungsi saling terikat dan menjadi satu arti, serta tidak dapat dipisahkan.

Predikat kompleks terbentuk ketika dua atau lebih elemen predikat bergabung ke dalam hubungan subjek dan objek. Setiap elemen predikat menambahkan argument ke dalam predikat mono klausa (Butt, 2013:8). Berikut contoh predikat kompleks dalam bahasa Gojri, salah satu bahasa rumpun Indo-Aryan (Bukhari, 2009:28):

1) Kaloo-neseb chil diyo.

'kaloo-ERG apple-NOM peelgivePREF'

'Kaloo mengupas apel (untuk orang lain).'

Kalimat tersebut merupakan predikat kompleks yang dibentuk dari verba chil dan diyo. Kalimat tersebut memiliki satu inti yaitu verba chil, sedangkan verba diyo merupakan light verba yang membawa makna benefaktif.

Berbagai macam penelitian tentang predikat kompleks dilakukan oleh beberapa ahli. Dalam bahasa Angkola Mandailing belum pernah dilakukan. Pantcheva (2009) mengkaji predikat kompleks dalam bahasa Persia berdasarkan Verbal Fase Pertama sintaksis yang dikembangkan oleh Ramchand (2008). Light verbs memberi 
makna leksikal bagi head verb ketika menguraikan frasa verba tersebut, sedangkan elemen preverbal menempati posisi rheme dan secara semantik menyatu dengan light verbs untuk membangun satu predikat gabungan. Selanjutnya, peran light verbs dan preverbal dalam menentukan struktur argumen dari keseluruhan predikat dan menunjukkan aspek sifat-sifat predikat kompleks tergantung pada interaksi antara verb dan light verbs. Hal ini sejalan dengan pernyataan Kumar (2013) bahwa predikat kompleks di Magahi merupakan kombinasi antara kata benda/kata sifat/ kata kerja dan verb light yang bersamasama membentuk predikat tunggal.

Basalu (2012) membahas secara rinci berbagai predikat kompleks dalam bahasa Telugu. Penelitian ini mengungkapkan proses sintaksis komposisi dan kendala pembentukannya. Kerangka yang digunakan adalah Sintaksis Fase Pertama (Ramchand 2008). Dalam pendekatan semantik leksikal, kendala terlihat pada makna dan struktur argument predikat kompleks, setiap kata kerja dipecah menjadi tiga sub-event heads yang menentukan sifat kata kerja. Predikat kompleks dibentuk oleh satu verb meringkas sub-event heads dari verb lain, dan ini dibatasi dengan cara berprinsip. Data dianalisis dan kendala yang dikembangkan dalam makalah ini berguna untuk ahli bahasa yang bekerja pada solusi komputasi untuk bahasa Telugu dan lainnya, untuk desain dan pengembangan fungsi struktur predikat dalam linguistik prosesor.

Li (2013) membahas pola leksikalisasi konstruksi predikat kompleks dalam bahasa Jepang. Penelitian ini berkontribusi untuk menemukan pola pembentuk predikat kompleks dalam bahasa Angkola Mandailing. Penelitian selanjutnya dilakukan oleh Mulyadi (2010), artikel ini memberikan kontribusi yang penting dalam cara menganalisis data yang ditemukan. Artikel ini menampilkan struktur internal frasa preposisi '(FP) dalam bahasa Indonesia dengan menggunakan teori X-bar. Hasil penelitian dalam artikel ini memperlihatkan bahwa sfruktur FP bahasa Indonesia dibentuk oleh komplemen, keterangan, dan spesifier. Kaidah pembentukannya dirumuskan sebagai berikut: (t) FP = P', Spes; $\mathrm{P}^{\prime}=\mathrm{P}^{\prime}$ Komp, (z) Fp = p', Spes; p'= p', Ket; p'= $\mathrm{P}$, Komp, FP = P', Spes; FP = P', Spes; $\mathrm{P}^{\prime}=\mathrm{P}$, Ket; $\mathrm{y}=\mathrm{p}$, Komp.

Penelitian selanjutnya dilakukan oleh Hafrianto dan Mulyadi (2018). Penelitian ini membahas struktur kalimat tanya dalam bahasa Melayu dialek Tamiang dengan menggunakan teori X-bar. Hasil penelitian ini menunjukkan bahwa jenis kalimat tanya total dalam bahasa Melayu dialek Tamiang memerlukan jawaban "ya" atau "tidak", sedangkan jenis kalimat tanya parsial dalam bahasa Melayu dialek Tamiang memerlukan jawaban penjelasan atau keterangan.

Penelitian lain juga dilakukan oleh Zahra dan Mulyadi (2019) membahas tentang teori X-bar dalam bahasa Mandailing. Artikel ini menampilkan struktur kalimat tanya sesuai dengan fungsi gramatikal dan leksikalnya dalam Bahasa Mandailing dengan menggunakan teori X-bar. Hasil penelitian dalam artikel ini memperlihatkan bahwa kalimat tanya parsial bahasa Mandailing memiliki fungsi gramatikal spesifier dan 
komplemen, sedangkan kalimat tanya total memiliki fungsi sebagai komplemen. Kalimat tanya bahasa Mandailing dapat dibangun oleh spesifier, komplemen, dan adverbial. Artikel ini berkontribusi karena sama-sama menggunakan teori X-bar dalam tataran kalimat.

Teori X-bar pertama kali dipelopori oleh Noam Chomsky pada tahun 1970 dan dikembangkan lebih lanjut oleh Ray Jackendoff pada tahun 1977. Culicover (1997:134) menyatakan bahwa teori $\mathrm{X}$-bar adalah teori struktur frasa. Berikut skema X-bar pada frasa tertinggi, yaitu frasa infleksi.
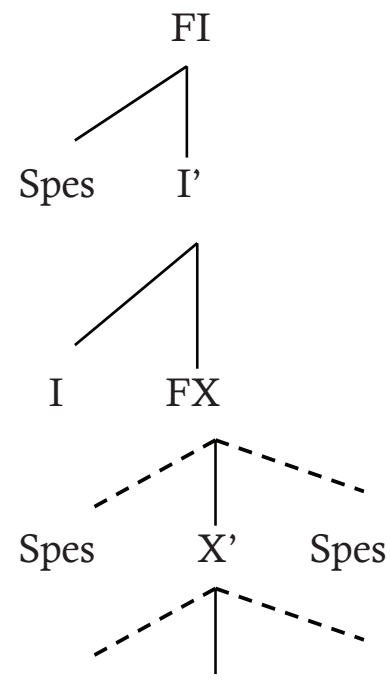

Komp X Komp

Keterangan:

$\mathrm{FI}=$ frasa infleksi (kalimat)

Spes $=$ spesifier

I' = infleksi bar — I ; FX

$\mathrm{I}=$ infleksi

FX = Frasa X (Verba,Nomina,Preposisi, dan Ajektiva) - X'; Spes (tentatif)

$\mathrm{X}^{\prime}=\mathrm{X}$ bar (Verba,Nomina,Preposisi, dan Ajektiva) X X; Komp (tentatif)

Komp $=$ komplement (tentatif)
Dari beberapa tinjauan pustaka di atas, artikel ini membahas predikat kompleks dalam bahasa Angkola Mandailing berdasarkan karakteristik, pola pembentuk, serta analisis teori X-bar dalam data yang ditemukan. Hal ini bertujuan untuk memperkenalkan bahasa Angkola Mandailing yang mulai tidak digunakan lagi dalam kehidupan seharihari dan masyarakat penutur bahasa Angkola Mandailing sendiri yang tidak mengerti dengan pola pembentuk bahasanya sendiri. Sesuai dengan Peraturan Daerah Sumatera Utara, yaitu Perda No. 8 Tahun 2017 tentangPengutamaan Bahasa Indonesia dan Perlindungan Bahasa dan Sastra Daerah (Gultom, 2018). Salah satu bahasa daerah yang perlu dilindungi adalah bahasa Angkola Mandailing. Salah satu cara untuk melindungi bahasa yang sudah mulai tidak digunakan tersebut adalah dengan melakukan penelitian, khususnya kajian sintaksis generatif, yaitu analisis menggunakan teori X-bar.

Berikut contoh predikat kompleks dalam bahasa Angkola Mandailing.

2) Umak kehe marmasak indahan, Ayah. 'Ibu Vaktif Vaktif nasi Ayah' 'Ibu pergi memasak nasi, Ayah'.

3) Uda mamili mambuat soban di kobun. 'Paman Vaktif Vaktif kayu di kebun' 'Paman memilih mengambil kayu di kebun'.

Dari contoh 2 dan 3 terdapat verba rumit yang disebut dengan predikat kompleks. Bahasa Angkola Mandailing yang paling banyak membentuk predikat kompleks adalah verba kehe 'pergi'. Verba kehe 'pergi' berpotensi untuk bergabung 
dengan verba lain dan membentuk predikat kompleks. Berikut contohnya:

4) Au kehe manabusi sira na isuruni Umak i.

'PronVaktif Vaktif garam yang disuruh ibu pron'

'Saya pergi membeli garam yang disuruh ibu saya'.

5) Umak kehe mampataruhon anggi tu sikola.

'Ibu Vaktif Vaktif adik ke sekolah'

'Ibu pergi mengantarkan adek ke sekolah'.

6) Aya kehe mangoban anggi tu poken. 'Ayah Vaktif Vaktif adik ke pasar' 'Ayah pergi membawa adik ke pasar'.

Dari dua contoh di atas, diketahui bahwa verba kehe 'pergi' memiliki potensi untuk bergabung dengan verba lain membentuk predikat kompleks. Verba kehe membentuk predikat kompleks apabila bergabung dengan verba manabusi 'membeli', mambuat 'mengambil', mampataruhon 'mengantarkan', marmasak 'memasak', mangoban 'membawa', malehen 'memberi', maridi 'mandi', dan lain-lain. Selain verba kehe, ada juga verba lain yang membentuk predikat kompleks, tetapi tidak seproduktif verba kehe, yaitu verba juguk 'duduk' yang bergabung dengan verba marsila 'bersila' dan verba mardua 'berdua', verba marsiajar 'belajar' yang dapat bergabung dengan verba mardalan 'berjalan' dan verba marmasak 'memasak', verba ro 'datang' yang bergabung dengan verba mangoban 'membawa', verba mamili 'memilih' yang bergabung dengan verba mambuat 'mengambil', dan verba manjalaki 'mencari' yang bergabung dengan verba karejo 'kerja'.

Dari penjelasan di atas diketahui predikat kompleks dalam bahasa Angkola Mandailing perlu dikaji karena ditemukan dalam bahasa Angkola Mandailing. Sebab itu, peneliti ingin mengulas lebih dalam dan secara saksama dengan menggunakan teori X-bar yang dikemukakan oleh Noam Chomsky, seorang ilmuwan yang mengemukakan bahwa frasa yang mempunyai struktur yang sama harus dikaji secara eksplisit. Sells mengemukakan bahwa gagasan dalam teori X-bar ialah bahwa di dalam struktur internal frasa yang berbeda dalam sebuah bahasa ditemukan pola yang sama pada setiap struktur (Mulyadi, 2010:3). Penelitian ini membahas predikat kompleks dalam bahasa Angkola Mandailing.

\section{METODE}

Penelitian ini dilaksanakan di masyarakat Angkola Mandailing yang berada di empat wilayah kabupaten, yaitu Kabupaten Tapanuli Selatan, Kabupaten Mandailing Natal, Kabupaten Padang Lawas Utara, dan Kabupaten Padang Lawas. Penelitian ini menggunakan pendekatan kualitatif dengan metode interaktif (Miles et.al, 2014) dengan teori X-bar. Data yang dikumpulkan berupa kata-kata dan bukan angka-angka dengan cara deskriptif dalam bentuk kata-kata dan bahasa pada suatu konteks khusus yang alamiah dan dengan memanfaatkan berbagai metode alamiah (Moleong, $2014: 6)$.

Sumber data penelitian adalah 
tuturan lisan informan dalam situasi tutur yang alamiah dan apa adanya. Ada tiga tahapan yang ditempuh dalam kajian ini, yaitu tahapan pengumpulan data, analisis data, dan penyajian hasil analisis data. Pada setiap tahap digunakan metode tertentu. Pada tahap pengumpulan data digunakan metode simak atau metode observasi. Dalam metode observasi, data direkam dan dicatat dari pengguna bahasa sehari-hari. Kemudian dikumpulkan kalimat yang mengandung predikat kompleks. Data yang berupa kalimat yang mengandung predikat kompleks kemudian diklasifikasikan menurut (1) karakteristik predikat kompleks, (2) pola pembentuk predikat kompleks, dan (3) analisis teori $\mathrm{X}$-bar predikat kompleks bahasa Angkola Mandailing.

Setelah data dikumpulkan, data dianalisis dengan metode agih, yaitu metode yang alat penentunya berupa bahasa itu sendiri. Metode agih ini diterapkan dengan teknik lesap, teknik sisip, teknik perluas, dan teknik balik (Sudaryanto, 1993:36). Langkah yang dilakukan dalam analisis data sebagai berikut. Pertama, data dibagi berdasarkan karakteristiknya dalam hal ini akan digunakan teknik-teknik dalam metode agih. Kedua, data tersebut dicocokkan untuk melihat pola-pola yang ada dalam predikat kompleks bahasa Angkola Mandailing. Ketiga, contoh data yang memiliki perbedaan dan dapat mewakili datalainnya akan dianalisis menggunakan teori X-bar. Teori X-bar digunakan untuk menganalisis dan mengidentifikasi data karena merupakan teori universal yang dapat digunakan kepada bahasa apa pun yang ada di dunia ini. Teori X-bar dengan menggunakan diagram pohon memberikan fungsi yang jelas untuk setiap katagori kata dalam bahasa Angkola Mandailing.

Dalam menyajikan hasil analisis data, digunakan metode informal. Penyajian hasil analisis data secara informal adalah penyajian hasil analisis dengan menggunakan kata-kata biasa sehingga mudah untuk dipahami dan dimengerti oleh pembaca.

\section{HASIL DAN PEMBAHASAN \\ Hasil \\ Karakteristik Predikat Kompleks dalam \\ Bahasa Angkola Mandailing}

Karakteristik Predikat Kompleks dalam Bahasa Angkola Mandailing sebagai berikut. (1) Predikat kompleks dibentuk dari dua verba, (2) predikat kompleks letaknya berdampingan, dan (3) predikat kompleks memiliki kesamaan aspek dan negasi.

Hal ini sejalan dengan pendapat Subiyanto (2010) tentang karakteristik verba beruntun dalam Nona Koelit Kuning sebagai berikut. (1) Predikat kompleks dibentuk dari dua verba atau lebih verbaverba inti, (2) predikat kompleks membentuk klausa tunggal dan letaknya berdampingan, dan (3) predikat kompleks memiliki kesamaan aspek dan negasi.

\section{Pola Pembentuk Predikat Kompleks dalam Bahasa Angkola Mandailing}

Pola pembentuk predikat kompleks dalam bahasa Angkola Mandailing ada empat, yaitu: (1) V1 intransitif + V2 intransitif, (2) V1 transitif + V2 intransitif, (3) V1 intransitif + V2 transitif, dan (4) V1 transitif + V2 transitif.

Hal yang sama juga dikemukakan 
oleh Oktaviana dan Muklish (2015), verba serial dalam bahasa Indonesia memiliki pola pembentuk (1) V1 transitif + V2 transitif, (2) V1 transitif + V2 taktransitif, (3) V1 taktransitif + V2 transitif, dan (4) V1 taktransitif + V2 taktransitif.

Dari pola yang ditemukan dalam pembentukan predikat kompleks bahasa Angkola Mandailing ditemukan formula sebagai berikut:

$\mathrm{V} 1$ intransitif $+\mathrm{V} 2$ intransitif $\mathrm{S}+\mathrm{P}_{1}+\mathrm{P}_{2}$

$\mathrm{V} 1$ transitif $+\mathrm{V} 2$ intransitif $\mathrm{S}+\mathrm{P}_{1}+\mathrm{P}_{2}$

$\mathrm{V} 1$ intransitif $+\mathrm{V} 2$ transitif $\mathrm{S}+\mathrm{P}_{1}+\mathrm{P}_{2}+\mathrm{O}+\{$ Ket $\}$

$\mathrm{V} 1$ transitif $+\mathrm{V} 2$ transitif $\mathrm{S}+\mathrm{P}_{1}+\mathrm{P}_{2}+\mathrm{O}+\{$ Ket $\}$

\section{Pembahasan}

Karakteristik Predikat Kompleks dalam Bahasa Angkola Mandailing

Pertama, predikat kompleks dibentuk dari dua verba. Predikat kompleks dalam bahasa Angkola Mandailing dibentuk oleh dua verba. Begitu juga dalam bahasa Gojri predikat kompleks hanya dibentuk oleh dua verba saja (Bukhari, 2009:4). Kedua verba tersebut membentuk satu verba inti. Contoh:

7) $\mathrm{Au}$ kehe manabusi sira naisuru ni Umak i.

'Pron Vaktif Vaktif garam yang disuruh ibu'

'Saya pergi membeli garam yang disuruh ibu saya'

Predikat kompleks pada contoh (7) adalah kehe manabusi 'pergi membeli'. Apabila salah satu unsurnya dilesapkan maka predikat kompleks menjadi verba tunggal. Hal itu dapat dibuktikan dengan melesapkan salah satu verba sebagai berikut.

7a. *Au kehe sira naisuru ni Umak i.

'PronVaktif garam yang disuruh ibu'

'*Saya pergi garam yang disuruh ibu.'

7b. Au manabusi sira naisuru ni Umak i. 'Pron Vaktif garam yang disuruh ibu'

'Saya membeli garam yang disuruh ibu.'

Lesapnya salah satu verba menyebabkan hilangnya predikat kompleks. Pada konstruksi (7a) kalimatnya menjadi tidak berterima karena pelesapan verba manabusi sedangkan pada konstruksi (7b) kalimatnya menjadi verba tunggal karena lesapnya verba kehe.

8) Umak kehe marmasak indahan.

'Ibu Vaktif Vaktif nasi'

'Ibu pergi memasak nasi'.

Predikat kompleks pada contoh (8) adalah kehe manjalaki 'pergi mencari kerja'. Apabila salah satu unsurnya dilesapkan maka terjadi dua kemungkinan, yaitu predikat kompleks tetap menjadi predikat kompleks atau kalimatnya menjadi tidak berterima. Hal itu dapat dibuktikan dengan melesapkan salah satu verba sebagai berikut.

8a. *Umak kehe indahan.

*'Umak Vaktif nasi'

*'Ibu pergi nasi'.

8b. Umak marmasak indahan.

'Umak Vaktif nasi'

'Ibu memasak nasi'.

Lesapnya salah satu verba menyebabkan hilangnya predikat 
kompleks. Pada konstruksi (8a) kalimatnya menjadi tidak berterima karena pelesapan verba marmasak sedangkan pada konstruksi (8b) kalimatnya menjadi verba tunggal karena lesapnya verba kehe. Pelesapan juga digunakan oleh Oktaviana dan Muklish (2015) untuk membuktikan karakteristik verba serial dalam bahasa Indonesia. Menurut Andrews perilaku konstruksi serial tidak berbeda dengan predikat kompleks (Subiyanto, 2010:176).

Predikat kompleks dalam bahasa Angkola Mandailing dibentuk oleh dua verba sejalan dengan penelitian yang dilakukan oleh Subiyanto (2010:178) dalam Nona Koelit Kuning bahwa verbaverba pembentuk KVB (predikat kompleks) merupakan verba inti yang membawa makna leksikal dan berpotensi untuk berdiri sendiri sebagai satu-satunya verba dalam klausa tunggal. Namun bedanya, dalam penelitian Subiyanto predikat kompleks dapat dibentuk oleh lebih dari dua verba. Berikut contoh klausa yang merupakan predikat kompleks dalam Nona Koelit Kuning.

9) Isteri Talip termenung memikirkan jawab suwaminya. (hlm.45)

10) Maka orang-orangnya itu pun datanglah berkerumun melihat aku. (hlm.58)

Dari klausa tersebut tergambar bahwa karakteristik predikat kompleks dalam bahasa Angkola Mandailing dan Nona Koelit Kuning sama-sama dibentuk oleh dua verba yang membentuk klausa tunggal. Namun, pada contoh (10) tergambar bahwa dalam Nona Koelit Kuning predikat kompleks dapat dibentuk dari tiga verba.
Penelitian ini sedikit berbeda dengan penelitian yang dilakukan oleh Basalu (2012). Dalam penelitian tersebut, Basalu membahas predikat kompleks nominal dalam bahasa Telugu.Sedangkan dalam penelitian ini hanya dibahas predikat kompleks dalam bentuk verba saja. Penelitian Kumar (2013) lebih kompleks lagi karena predikat kompleks di Magahi dilihat melalui kombinasi antara kata benda, kata sifat atau kata kerja yang berhubungan dengan verb light yang bersama-sama membentuk predikat tunggal. Menurut penelitian Kumar predikat kompleks tidak hanya dibentuk oleh verb saja tetapi bisa dibentuk dari kombinasi nomina (kata benda) dengan verb light, ajektiva (kata sifat) dengan verb light, atau antara verb (kata kerja) dengan verb light.

Kedua, predikat kompleks letaknya berdampingan. Predikat kompleks dalam Bahasa Angkola Mandailing letaknya berdampingan. Berikut contohnya:

11) Ia mangoban marlojong adaboru $i$. 'Dia Vaktif Vaktif anak gadis itu'

'Dia membawa lari anak gadis itu.'

12) Ani marsiajar marmasak dohot umak nia i dapur.

'Ani Vaktif Vaktif dengan ibu pron di dapur'

'Ani belajar memasak dengan ibunya di dapur'

Letak verba predikat kompleks pada contoh (11) (12) berdampingan. Untuk membuktikan kadar keeratan verba mangoban marlojong 'membawa lari' dan marsiajar marmasak 'belajar memasak' digunakan teknik sisip. Teknik sisip 
dilakukan dengan cara menyisipkan konjungtor di antara predikat verba tersebut. Hal itu dapat dibuktikan sebagai berikut.

11a) *Ia mangoban dot marlojong adaboru i.

*'PronVaktif dan Vaktif anak gadis itu.'

'*Dia membawa dan lari anak gadis itu.'

12a) *Ani marsiajar dot marmasak dohot umak nia i dapur.

*'Ani Vaktif dan Vaktif dengan ibu pron di dapur'

*'Ani belajar dan memasak dengan ibunya di dapur'

Penyisipan konjungsi dot di antara verba mangoban 'membawa' dan marlojong 'lari' pada konstruksi (11a) serta verba marsiajar 'belajar' dan marmasak 'memasak' pada konstruksi (12a) menyebabkan kalimat tersebut tidak berterima. Hal ini menunjukkan bahwa letak kedua verba pada predikat kompleks berdampingan.

Nilu dan Rajesh (2012) mengatakan bahwa predikat kompleks adalah unit frasa yang dapat diintervensi urutannya oleh beberapa elemen, yaitu partikel, adverbia, interogatif, dan negasi. Contohnya:

13) paDhe me okar madad bhi karhu 'study in his help part. Do'

'Do help him in his studies.'

Di Magahi, bhii 'juga' adalah partikel intensifier dapat mengintervensi di antara urutan kata kerja majemuk. Dalam contoh (13), partikel bhii berfungsi untuk menambahkan upaya pada beberapa aksi.
14) yaad baRii din par karlii hamanii ke!

'remember very day on do us of'

'You remembered us after a long time!'

Dalam contoh (14) tergambar bahwa diMagahi, adverbia dapat mengintervensi dalam konstruksi predikat kompleks dan membentuk kalimat yang tidak gramatik.

Ketiga, predikat kompleks memiliki kesamaan aspek dan negasi. Predikat kompleks dalam Bahasa Angkola Mandailing memiliki aspek dan negasi. Berikut contohnya:

15) Ompung madung ro manjalaki ho. 'Nenek sudah Vaktif Vaktif Pron.' 'Nenek sudah datang mencari kamu.'

16) Imana madung kehe mampataruhon indahan tu aya nia.

'Pron sudah Vaktif Vaktif nasi kepada ayah pron'

'Dia sudah pergi mengantarkan nasi untuk ayahnya'.

17) Danak nia i inda dope marsiajar mardalan i.

'Anak Pron belum Vaktif Vaktif itu.'

'Anaknya belum belajar berjalan.'

18) Abangku inda dope ro mangoban silua tu bagas.

'Abang Pron belum Vaktif Vaktif oleh-oleh ke rumah'

'Abangku belum datang membawa oleh-oleh ke rumah'.

Kalimat (15) (16) mengandung verba yang memiliki kesamaan penanda aspek sudah, sedangkan kalimat (17) (18) mengandung verba yang memiliki 
kesamaan penanda negasi tidak. Penanda aspek pada bentuk madung ro manjalaki 'sudah datang mencari' dan madung kehe mampataruhon 'sudah pergi mengantarkan' serta penanda negasi pada bentuk inda dope marsiajar mardalan 'belum belajar berjalan' dan inda dope ro mangoban 'belum dating membawa' tidak hanya berhubungan dengan verba pertama melainkan dengan kedua verbanya. Akan tetapi, letak aspek dan negasi tersebut hanya di depan verba pertama. Hal itu dibuktikan dengan memperluas aspek dan negasi pada kedua verba berikut ini.

15a)*Ompung madung ro madung manjalaki ho.

'*Nenek sudah Vaktif sudah Vaktif Pron.'

'*Nenek sudah datang sudah mencari kamu.'

16a) *Imana madung kehe madung mampataruhon indahan tu aya nia.

*'Pron sudah Vaktif sudah Vaktif nasi kepada ayah pron'

*'Dia sudah pergi sudah mengantarkan nasi untuk ayahnya'.

17a) *Danak nia $i$ inda dope marsiajar inda mardalan $i$.

"*Anak Pron belum Vaktif belum Vaktif.'

'*Anaknya belum belajar belum berjalan.'

18a) *Abangku inda dope ro inda mangoban silua tu bagas.

'Abang Pron belum Vaktif belum Vaktif oleh-oleh ke rumah'

'Abangku belum datang belum membawa oleh-oleh ke rumah'.

Pada konstruksi (15a), (16a), (17a) dan (18a) tidak berterima. Pemakaian aspek dan negasi yang berlebihan menjadikan kalimat tidak efektif dan tidak dimengerti oleh pendengar atau pembaca.

Perhatikan pula contoh dalam bahasa Mahagi berikut ini.

19) a. "ham khaa naa lelii

'I eat not taken'

'I have eaten.'

b. ham naa khailii.

'I not eaten'

'I haven't eaten.' (Nilu dan Rajesh, 2012:28)

Dari contoh (19a) tersebut diketahui bahwa penanda negasi tidak dapat mengintervensi urutan kata kerja majemuk khaa 〈eat dan lelii 〈takes. Lebih tepatnya, negasi hadir sebelum verba inti yang menggabungkan fitur light verb juga. Seperti pada contoh (19b), khailii 'dimakan' menggabungkan kata kerja cahaya lelii «diambil' hanya dalam kata kerja utama. Dengan demikian, diketahui bahwa penggunaan aspek dan negasi pada predikat kompleks adalah sama dan diletakkan sebelum verba pertama atau verba inti.

Keempat, pola pembentuk predikat kompleks dalam bahasa Angkola Mandailing. Pola pembentuk predikat kompleks, yaitu: (1) V1 Intransitif + V2 Intransitif; (2) V1 transitif + V2 intransitif, (3) V1 intransiyif + V2 transitif, (4) V1 transitif + V2 Transitif. Berikut ini contoh masing-masing pola predikat kompleks.

Pertama, pola V1 Intransitif + V2 Intransitif.

Contoh:

20. Ayah juguk marsila. 
'Ayah Vaktif Vaktif.'

'Ayah duduk bersila.'

21. Abang kehe maridi tu Parsariran.

'Abang Vaktif Vaktif ke Parsariran'.

'Abang pergi mandi ke Parsariran'.

Kedua, pola V1 transitif + V2 intransitif.

Contoh:

22. Etek malehenkon masuk.

'Tante Vaktif Vaktif'

'Tante mempersilahkan masuk.'

Ketiga, pola V1 intransitif+ V2 transitif.

Contoh:

23. Umak kehe mampataruhon anggi tu sikola.

'Ibu Vaktif Vaktif adik ke sekola.'

'Ibu pergi mengantarkan adik ke sekolah.'

24. Umak kehe marmasak indahan.

'Ibu Vaktif Vaktif nasi'.

'Ibu pergi memasak nasi'.

Keempat, pola V1 transitif + V2 Transitif.

Contoh:

25. Uda mamili mambuat soban di kobun.

'Paman Vaktif Vaktif kayu di kebun.'

'Paman memilih mengambil kayu di kebun.'

26. Ia mamili manyapu bagas.

'Pron Vaktif Vaktif rumah'

'Dia memilih menyapu rumah'.

Dari contoh di atas diketahui pola pembentuk predikat kompleks bahasa Angkola Mandailing ada empat, yaitu: (1) V1 intransitif+V2 intransitif, (2) V1
transitif+V2 intransitif, (3) V1 intransif+V2 transitif, dan (4) V1 transitif+ V2 transitif. Pola ini sama dengan pola pembentuk predikat kompleks dalam bahasa Jepang (Li:2013). Dalam penelitiannya Li menggunakan pola formasi senyawa V-V yang diperkenalkan oleh Yumoto, sebagai berikut.

a. Pair relation

Misalnya: kake-meguru 'run about', hashiri-mawaru 'run about'

b. Means

Misalnya: tsuki-otosu 'push-cause. fall', naki-otosu 'cry-cause.fall'

c. Cause-effect

Misalnya: obore-shinu 'drown die', yake-shinu 'burnt die'

d. Accompanying state/manner Misalnya: hai-yoru 'crawl towards', koroge-otiru 'tumble-fall'

e. Complement relation

Misalnya: tsukai-konasu 'use something efficiently', kaki-otosu 'forget to write'

Dari kelima formasi tersebut, tergambar bahwa pola pembentuk predikat kompleks bahasa Jepang juga ada empat, yaitu: (1) V1 intransitif+V2 intransitif, (2) V1 transitif+V2 intransitif, (3) V1 intransif $+\mathrm{V} 2$ transitif, dan (4) V1 transitif+ V2 transitif.

\section{Analisis teori X-bar predikat kompleks dalam bahasa Angkola Mandailing}

Pada uraian selanjutnya, disajikan analisis teori X-bar pada predikat kompleks dalam bahasa Angkola Mandailing. Analisis dengan mengacu pada beberapa skema konstruksi predikat kompleks. 
Pertama, Skema Predikat kompleks V1 intransitif + V2 intransitif.

1)

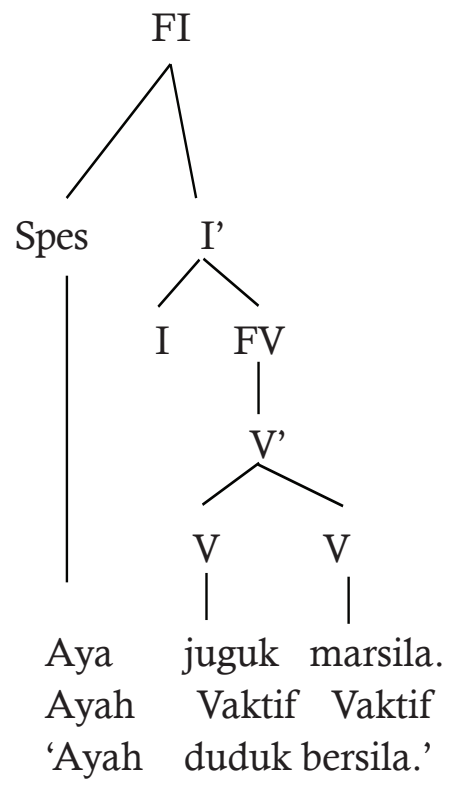

Pada skema 1 digambarkan bahwa predikat kompleks juguk marsila 'duduk bersila' berkombinasi membentuk V' dalam skema ini komplemen tidak ada sehingga V' membentuk frasa verba. Frasa verba berkombinasi dengan infleksi yang dalam kalimat ini tidak tertulis membentuk I'. I' berkombinasi dengan spesifier Aya membentuk frasa infleksi (kalimat). Skema ini sama dengan D-skema yang digambarkan oleh Ehineni (2014) hanya saja dalam pembahasan yang disebutkan Ehineni untuk pembentukan V' terjadi karena kombinasi verba dan frasa nomina, serta kombinasi antara verba dan frasa adverbia.

Formula: $\mathrm{S}+\mathrm{P}_{1}+\mathrm{P}_{2}$
Kedua, Skema Predikat kompleks V1 intransitif + V2 transitif

2)

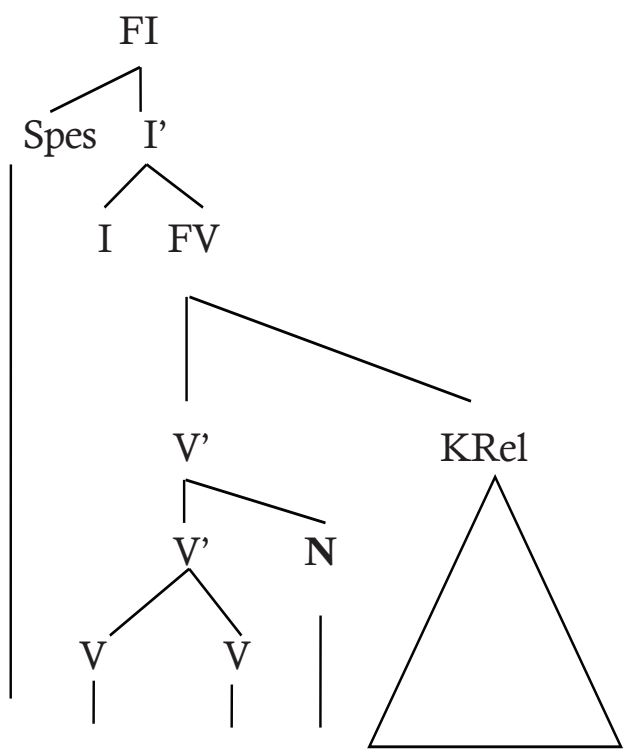

Au kehe manabusi sira nai suru ni Umak i. 'Pro Vaktif Vaktif garam yang disuruh ibu itu'

'Saya pergi membeli garam yang disuruh ibu saya'.

Pada skema 2 digambarkan bahwa predikat kompleks kehe manabusi 'pergi membeli' berkombinasi membentuk V' dalam skema $\mathrm{V}$ ' berkombinasi dengan nomina sira membentuk V' kedua. V' kedua berkombinasi dengan klausa relatif nai suru ni Umak $i$ 'yang disuruh ibu saya' membentuk frasa verba. Frasa verba berkombinasi dengan infleksi yang dalam kalimatini tidak ditulis membentuk I'. I' berkombinasi dengan spesifier au membentuk frasa infleksi (kalimat).

$$
\text { Formula: } \mathrm{S}+\mathrm{P}_{1}+\mathrm{P}_{2}+\mathrm{O}+\{\mathrm{Ket}\}
$$


Ketiga, Skema Predikat kompleks V1 transitif + V2 transitif

3)

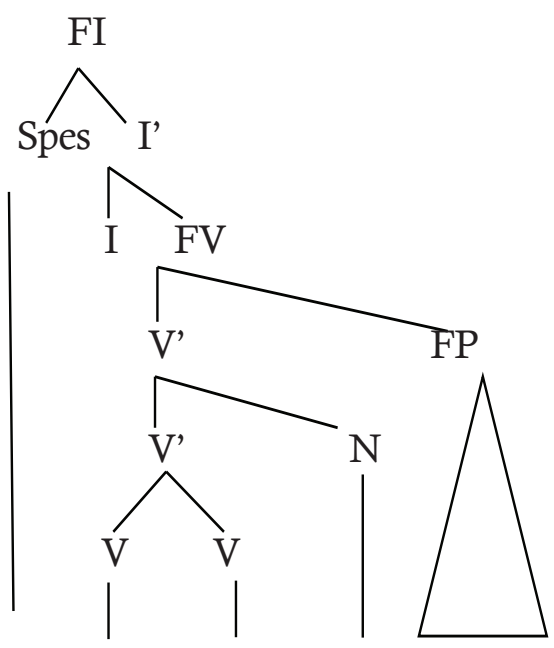

Uda mamili mambuat soban di kobun. 'Paman Vaktif Vaktif kayu di kebun'.

'Paman memilih mengambil kayu di kebun'.

Pada skema 3 digambarkan bahwa predikat kompleks mamili mambuat 'memilih mengambil' berkombinasi membentuk V'. Dalam skema V' berkombinasi dengan nomina soban membentuk V' kedua. V' kedua berkombinasi dengan frasa preposisi membentuk frasa verba. Frasa verba berkombinasi dengan infleksi yang tidak dituliskan membentuk I'. I' berkombinasi dengan spesifier $u d a$ membentuk frasa infleksi (kalimat).

Formula: $\mathrm{S}+\mathrm{P}_{1}+\mathrm{P}_{2}+\mathrm{O}+\{$ Ket $\}$
Keempat, Skema Predikat kompleks V1 transitif + V2 intransitif

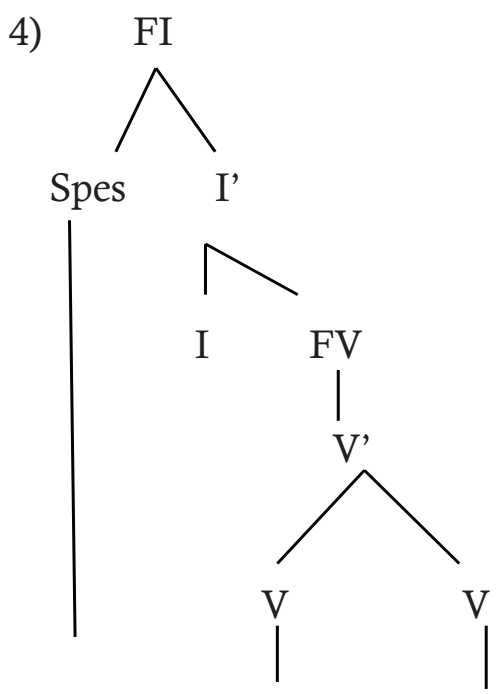

Etek malehenkon masuk

'Tante Vaktif Vaktif'

'Tante mempersilahkan masuk'

Pada skema 4 digambarkan bahwa predikat kompleks malehenkon masuk 'mempersilahkan masuk' berkombinasi membentuk V'. Dalam skema V' membentuk frasa verba. Frasa verba berkombinasi dengan infleksi yang tidak dituliskan membentuk I'. I' berkombinasi dengan spesifier etek membentuk frasa infleksi (kalimat). Skema 2, 3, dan 4 memiliki kemiripan dengan gambaran konfigurasi predikat kompleks dalam penelitian Kumar (2013).

$$
\text { Formula: } \mathrm{S}+\mathrm{P}_{1}+\mathrm{P}_{2}
$$


Dari empat skema tersebut diketahui bahwa analisis teori X-bar konstruksi predikat kompleks bahasa Angkola Mandailing dibentuk dari kombinasi dua verba yang berdampingan untuk menghasilkan V'. Hal ini membuktikan bahwa kedua verba tersebut sama-sama menjadi verba inti dalam kalimat.V1, V2 sama-sama memiliki peran dan jika dilesapkan salah satu verbanya konstruksinya menjadi tidak berterima atau menjadi verba tunggal yang berbeda makna dengan makna sebelum dilesapkan. Jika dibandingkan dengan penelitian yang dilakukan oleh Soraya dan Mulyadi (2018) terkait kalimat tanya dalam bahasa Mandailing yang juga menggunakan teori X-bar, terlihat perbedaan antara penerapan teori X-bar dalam kalimat tanya dan juga dalam konstruksi predikat kompleks. Dalam kalimat tanya skemanya adalah $\mathrm{X}$ berkombinasi dengan komplemen membentuk X'. X' berkombinasi dengan spesifier membentuk XP (frasa X). XP berkombinasi dengan I membentuk I'. I' berkombinasi dengan spesifier membentukIP (kalimat). IP berkombinasi dengan $\mathrm{C}$ membentuk C'. C' membentuk proyeksi tertinggi yaitu $\mathrm{CP}$. Contohnya pada kalimat tanya berikut ini.

Umak mamio ise?

'Ibu memanggil siapa?'

Analisis X-barnya adalah verba mamio 'memanggil' berkombinasi dengan NP ise 'siapa' membentuk V'. V' membentuk VP (frasa verba). VP berkombinasi dengan I dalam hal ini tidak tergambarkan dalam kata membentuk I'. I' berkombinasi dengan spesifier umak 'ibu' membentuk IP (kalimat). IP berkombinasi dengan C membentuk C'. C' membentuk proyeksi tertinggi yaitu CP. Kata tanya dalam hal ini berfungsi sebagai C (komplemen).

Dalam konstruksi predikat kompleks skemanya adalah predikat kompleks (V1+V2) berkombinasi membentuk V'. V' membentuk FV. FV berkombinasi dengan I membentuk I'. I' berkombinasi dengan Spes membentuk FI (kalimat). Dalam hal ini predikat kompleks berfungsi sebagai inti dari kalimat tersebut yang disimbolkan dengan huruf $\mathrm{V}$.

Keempat skema tersebut juga membuktikan pola pembentuk predikat kompleks bahasa Angkola Mandailing ada empat sama dengan pola pembentuk predikat kompleks dalam bahasa Jepang (Li:2013), yaitu: (1) V1 intransitif + V2 intransitif, (2) V1 transitif + V2 intransitif, (3) V1 intransif + V2 transitif, dan (4) V1 transitif + V2 transitif.

\section{SIMPULAN}

Karakteristik predikat kompleks dalam bahasa Angkola Mandailing sebagai berikut. (1) predikat kompleks dibentuk dari dua verba atau lebih, (2) predikat kompleks letaknya berdampingan, dan (3) predikat kompleks memiliki kesamaan aspek dan negasi.

Pola pembentuk predikat kompleks dalam bahasa Angkola Mandailing ada empat, yaitu: (1) V1 intransitif + V2 intransitif, (2) V1 transitif + V2 intransitif, (3) V1 intransitif + V2 transitif, dan (4) V1 transitif + V2 transitif.

Analisis teori X-bar konstruksi predikat kompleks bahasa Angkola Mandailing dibentuk dari kombinasi dua verba yang berdampingan untuk 
menghasilkan V'. Hal ini membuktikan bahwa kedua verba tersebut sama-sama menjadi verba inti dalam kalimat. Temuan dalam penelitian ini dapat dikaji lebih lanjut untuk penelitian berikutnya.

\section{UCAPAN TERIMAKASIH}

Alhamdulillah sebagai rasa syukur disampaikan kepada Allah SWT yang telah memberikan kemudahan dalam menyelesaikan artikel ini. Ucapan terima kasih disampaikan kepada teman sejawat yang telah membantu telaah dan pembahasan artikel ini.

\section{DAFTARPUSTAKA}

Alsina, A., Bresnan, J., Sels, P.(1997). Complex Predicates. Stanford, CA: CSLI Publications.

Balusu, R. (2012). Complex Predicates in Telugu: A Computational Perspective. Makalah disajikan pada Seminar COLING 2012: Demonstration COLING. (Kay, M \&Boitet, C., eds), EFL University, Mumbai, India. pp 1-8. https://www.aclweb.org/anthology/ C12-3001.pdf.

Bukhari, N. (2009). A Comparative Study of Gojri Double Verb Constructions. Language in India, 9(1), 27-51. http:// www. languageinindia.com/ jan2009/doubleverbgojri.pdf.

Butt, M. (2013). Complex Predicate Puzzles. Makalah disajikan pada Workshop Approaches to Complex Predicates. University of Konstanz, Paris, May 29-31. https://www. ling.uni-konstanz.de/typo3temp/ secure_downloads/82191/096f59e6 0896f41c1882246f4d0d72ec32c/ paris13-cps.pdf.
Culicover, P.W. (1997). Principtes and Paramaters: An tntroduction to Syntactic Theory. Oxford: Oxford University Press.

Ehineni, T.O. (2014). A Syntactic Analysis of Lexical and Functional Heads in Nigerian English Newspaper Headlines. International Journal of Linguistics, 6(5), 9-21. http://www.macrothink.org/ journal/index.php/ij1/article/ view/6110.

Gultom, J. (2018, 21 Februari). Pelestarian Bahasa Ibu (Bahasa Daerah) Melalui Media Sosial. http://www.medanbisnisdaily.com/ $\mathrm{n}$ e $\mathrm{w}$ s / $\mathrm{o} \quad \mathrm{n} 1$ i $\mathrm{n}$ e / $\mathrm{read} / 2018 / 02 / 21 / 26170 /$ pelestarian_bahasa_ibu_bahasa_ daerah_melalui_media_sosial/.

Hafrianto, J \& Mulyadi. (2018). Kalimat Tanya dalam Bahasa Melayu Dialek Tamiang. Litera Jurnal Penelitian Bahasa, Sastra, dan Pengajarannya, 17(2), 186-201. https://doi. org/10.21831/1tr.v17i2.20225.

Hendrickx, I, et al. (2010). Complex Predicates Annotation in a Corpus of Portuguese. Makalah disajikan pada Fourth Linguistic Annotation Workshop ACL. Uppsala, Sweden. Hal 100-108. https://www.clul. ulisboa.pt/files / anagrama / CPportfinal.pdf.

Kumar, R. (2013). Agreement in Magahi Complex Predicate. International Journal of Linguistics, 5(1), 176-190. http: / /www.macrothink.org / journal/index.php/ij1/article/ view/3304. 
Li, W. (2013). Lexicalisation Patterns of Complex-Predicate Constructions in Japanese. International Journal of Linguistics, 5(4), 178-187. http:// www.macrothink.org/journal/ index.php/ijl/article/view/3989.

Miles, M.B., Huberman, M., Saldaña, J. (2014). Qualitative Data Analysis: A Methods Sourcebook (edisi 3). Thirdedition. Sage: London.

Moleong, J.L. (2014). Metode Penelitian Kualitatif , Edisi Revisi. PT Remaja Rosdakarya, Bandung.

Mulyadi. (2010). Frasa Preposisi Bahasa Indonesia: Analisis X-Bar. Jurnal Kajian Sastra, 34(1), 1-12. http:// ejournal.undip.ac.id/index.php/ $\mathrm{kaj}$ i a n s a s tra/editor/ submission/2671.

Nilu \& Rajesh, K. (2012). Phrasal Integrity in Magahi Complex Predicates. OSR Journal of Humanities and Social Science (JHSS), 3(1), 25-30. DOI: 10.9790/0837-0312530.

Oktaviana, D., \& Mukhlish. (2015). Verba Serial dalam Bahasa Indonesia. Jurnal Caraka, 1(2), 5058. http://jurnal.ustjogja.ac.id/ index.php/caraka/article / view/1915/1081.

Pantcheva, M. (2009). First Phase Syntax of Persian Complex Predicates: Argument Structure and Telicity. JSAL, 2(1), 53-72. https://ojs.ub. uni-konstanz.de/jsal/index.php/ jsal/article/view/7.

Ramchand, G. (2008). Verb Meaning and the Lexicon: A First Phase Syntax. Cambridge: Cambridge University Press.

Subiyanto, A. (2010). Konstruksi Verba Beruntun dalam Nona Koelit Koetjing. Makalah disajikan pada Seminar Nasional Pemertahanan Bahasa Nasional. Universitas Diponegoro, Semarang. Hal 176-184. https:// core.ac.uk/reader/11735325.

Sudaryanto. (1993). Metode dan Aneka Teknik Analisis Bahasa. Yogyakarta: Duta Wacana UniversityPress.

Zahra, T.S. \& Mulyadi. (2019). Kalimat Tanya dalam Bahasa Mandailing: Teori X-Bar. Retorika: Jurnal Bahasa, Sastra, dan Pengajarannya, 12(2), 235242. https://ojs.unm.ac.id/retorika/ article/view/9315. 